\title{
MICROBICIDAL EVALUATION OF PLANT EXTRACTS - IRON METAL IONS COMPLEX
}

\author{
AMARISH KUMAR SHARMA ${ }^{*}$, JASVIR KAUR ${ }^{1}$, ANJANA RANA SHARMA ${ }^{2}$ \\ ${ }^{1}$ Department of Bioengineering and Biosciences, Lovely Professional University, Phagwara, Punjab, India. ${ }^{2}$ Department of Biotechnology, \\ Gyan Vihar University, Jaipur, Rajasthan, India. Email: amarish.19824@lpu.co.in
}

Received: 08 May 2017, Revised and Accepted: 30 June 2017

ABSTRACT

Objective: The aim of this study is to screen and evaluate the antimicrobial or microbicidal effect of plant metabolites, conjugated with essential iron metal ions.

Methods: First batch of study includes screening of antimicrobial activity of leaves of mint (Mentha), methi (Trigonella foenum-graecum), and neem (Azadirachta indica) against Bacillus, Aspergillus, and Rhizopus sp., respectively. Inhibition of microbial growth and propagation was investigated using agar well diffusion method (minimum inhibitory concentration evaluation). Antibiotic agent, streptomycin sulfate, and antimycotic agent, and fluconazole was used as a positive control. The polar, non-polar, and aqueous extracts of plants leaves of abovementioned plant species were screened for their antibacterial activity against Bacillus sp. and antifungal activity against Aspergillus and Rhizopus sp. and their mix culture, respectively. Second batch of study includes evaluation of combinatorial effect of plant extracts of mint (Mentha piperita), methi (T. foenum-graecum), and neem (A. indica) complexed with ferric ions ( $\mathrm{Fe}^{3+}$, Iron metal ions) in concentrations at acceptable dosage range.

Results: The antibacterial and antifungal activity of the plants leaves extracts in different combinations was evaluated. The plant extracts from selected plant of neem, methi, and mint after conjugation with essential iron metal ions and at a concentration of $100 \mathrm{mg} / \mathrm{ml}$ show an enhanced microbicidal (2-3 fold) activity compared to only plant extracts used in the experiment.

Conclusion: Based on the above investigation, it can be concluded that the plant extracts possessing antimicrobial property when conjugated with essential metal ions (iron metal ions) show enhanced antimicrobial efficacy compared to only plant extracts used. The result from this investigation could be very helpful in the food preservation and packaging industry.

Keywords: Mint, Methi, Neem, Antimicrobial activity, Bacillus, Aspergillus, Rhizopus, Iron metal ions.

(C) 2017 The Authors. Published by Innovare Academic Sciences Pvt Ltd. This is an open access article under the CC BY license (http://creativecommons. org/licenses/by/4. 0/) DOI: http://dx.doi.org/10.22159/ajpcr.2017.v10i10.19687

\section{INTRODUCTION}

Bakery products were reported to be $9 \%$ of the average weekly food consumption [1,2] reported in 1990, and in the UK, the consumption of bread is $41.5 \mathrm{~kg}$ per person. In the historical perspective, for hundreds of years, man has used wheat and other cereals to produce bread with an average consumption of about $65 \mathrm{~kg}$ of bread per capita per year in Europe, and it remains an important constituent of a balanced healthy diet [2]. Wheat flour contains two fractions of proteins; water soluble fraction, i.e., albumin, globulin, and proteases and water insoluble fractions, i.e., gluten and gliadin. White bread makes from flour containing only the central core of the grains (endosperm). Bread is the best source for carbohydrates. Although bread also contains other components such as dietary fibers, fats, proteins, thiamine, riboflavin, niacin, folate, choline, vitamin $\mathrm{k}$, calcium, iron, magnesium, potassium, and sodium. The major problem associated is to maintain the prolonged shelf life of baked products, which is prone to be contaminated with molds. Molds spoilage is one of most serious and costly problems for bakery industry. Carbohydrates are one of the best sources for molds growth on bread products. Since bread contains a large amount of carbohydrates and less amount of water, so it does not provides favorable conditions in carbohydrate rich food for growth of other microorganisms except molds. Bread's molds live, feed, and reproduce on bread. Molds are heterotrophic organisms and do not perform photosynthesis. Molds consist hyphae, which entered into bread, secrete hydrolytic enzymes through hyphal tips and uses nutrients and energy from it. Molds break glycosidic linkages between glucose residues in bread's starch and used glucose as energy source. Molds spores generally found in air which makes them easier to contact with bread products. The molds mainly involved in spoilage of bread include Rhizopus sp., Mucor sp., Penicillium sp., Eurotium sp.,
Aspergillus sp., and Monilia sitophila [3]. Molds generally attack on simple dough, not on sour dough, due to acidification. Antifungal low molecular weight compounds, peptide, and proteins are generally synthesized by lactic acid bacteria in sour dough [4-6]. The Aspergillus genus comprises approximately 180 species in which 34 species have been associated with human disease [7]. Majority of human specific diseases are caused by Aspergillus fumigatus and Aspergillus niger, and, less frequently by Aspergillus flavus and Aspergillus clavatus. Aspergillus produced conidia by asexual reproduction is small (2-10 $\mathrm{mm}$ in diameter) and hydrophobic, which aids aerosolization [8]. Various species related to Aspergillus genus cause allergy [9-11], asthma [12,13], allergic bronchopulmonary aspergillosis [9,13,14], chronic cavitary pulmonary aspergillosis [15], chronic necrotizing, chronic necrotizing pulmonary aspergillosis, aspergilloma, and invasive aspergillosis. The patients who have allergic bronchopulmonary aspergillosis have been shown to have an increased frequency of the cystic fibrosis gene mutation, but a causative role of gene has not yet been well described [16]. The invasive aspergillosis is a rapidly progressive disease, often occurs in immunosuppressed patients, those who have received bone marrow or solid organ transplants, and patients with advanced AIDS or chronic granulomatous disease. Bread products also contaminated by yeast was characterized by visible growth on the surface of products. The spores of Bacillus subtilis were present in raw ingredients such as flour, sugar, and yeast, causes' rope in bread [17]. Ropey bread is characterized by changes color from brown to black, rotten fruit odor [18]. This problem probably occurs in the summer season when the climate is warm and humid [17]. Ropiness was caused mainly by B. Subtilis, but other species of Bacillus are capable of causing rope and these include Bacillus licheniformis, Bacillus megaterium, and Bacillus cereus [19]. Ropiness is the most important spoilage of bread after moldiness, occurs mostly in summer, when climatic conditions 
favor growth of bacteria. Preservatives help to reduce or prevent spoilage caused by molds and bacteria. Chemical preservatives can control the molds growth by preventing the metabolism, denaturation of protein, by causing physical damage to the cell membrane [20]. Calcium propionate and propionic acid are usually used at concentrations of 0.2 and $0.1 \%$, respectively, to inhibited molds for 2 days or more, and formation of rope was also prevented [21]. Sorbic acid is much effective in inhibiting molds growth at concentration of $0.125-0.3 \%$. Higher doses of calcium propionate have been observed to be lethal for human beings. Cancerlike tumors appeared in rats, fed with propionic acid concentration up to $4 \%$ lead to prohibition of the use of calcium propionate in some European countries [22]. Prolonged preservation of breads with high concentration of calcium propionate is observed to stimulate the growth of resistant strains of Penicillium roqueforti [23]. Since few years ago, the European directive on preservations [24] decreased the permitted concentration of sorbate and propionate to 0.2 and 0.3 (wt/wt), respectively. Therefore, to introduce some eco-friendly alternative control strategies for food safety, the best available alternative is naturally occurring derivatives.

As far as neem (Azadirachta indica) is concerned, it is popularly known for its antimicrobial property. Each of the plant parts is consisting of the different class of essential secondary metabolites. It is experimentally proved through various research studies that neem seeds contain chemical compounds which can check the population of 100 species of insects and microorganisms. Neem leaves have been proven to be an effective source of antimicrobial metabolites. We are also aware that most of the pathogens infecting animal and plants and airborne. Treatment with neem leaves smoke could easily check the airborne bacterial growth, and since it is cost effective, it can be commercially utilized [25]. Similarly, Mentha piperita is an important plant of medicinal importance and is prevalent in North America, Asia, and Europe. $M$. piperita is mainly cultivated for its peppermint oil which is extracted from the leaves of flowering plant. It is also used as environmentally friendly insecticide $[25,26]$. Hence, plants extract is the best option to inhibit the growth of molds, without any side effects on human's health.

\section{METHODS}

\section{Collection of plant parts}

The leaves of three plants species, mint (Mentha), methi (T. foenumgraecum), and neem (A. indica), were collected from Anandpur Sahib, Ropar, Punjab $\left(31.23^{\circ} \mathrm{N} 76.50^{\circ} \mathrm{E}\right)$.

\section{Food sample}

White bread was exposed to open atmosphere (temperature: $24-30^{\circ} \mathrm{C}$; humidity: $50 \%$ ) till the microbes spoiled the food. All the microbes present on the white bread sample were screened for further identification and characterization.

\section{Plant extract preparation}

Leaf extracts of mint (Mentha), methi (T. foenum-graecum), and neem $(A$. indica) were prepared using standardized protocol [27]. Polar extracts (ethanol, methanol, and acetone), non-polar extracts (chloroform), and aqueous extracts (distilled water) were prepared in three concentration range, i.e., $1 \mathrm{mg} / \mathrm{ml}, 10 \mathrm{mg} / \mathrm{ml}$, and $100 \mathrm{mg} / \mathrm{ml}$, respectively, for the above leaf extracts.

Polar extracts were prepared by dissolving $10 \mathrm{~g}$ of washed, dried, and crushed leaves of the chosen plants, using mortar and pestle, in $100 \mathrm{ml}$ of pure ethanol, methanol, and acetone solvents. The plant extracts were placed on a water bath for 30-40 minutes followed by simultaneous shaking in a bio-incubator at $250 \mathrm{rpm}$ for $48 \mathrm{hrs}$. Once the extracts are recovered after appropriate shaking, they are filtered, evaporated to dryness, and stored at $4^{\circ} \mathrm{C}$ till further use $[19,27]$.

\section{Test organisms}

The pathogenic bacteria included in the present study were B. subtilis (MTCC-441), A. niger (MTCC-404), and the species of Rhizopus stolonifer (MTCC-162) procured from Institute of Microbial Technology (IMTECH), Chandigarh, India.

\section{Salts and growth media}

Ferric chloride hexahydrate $\left(\mathrm{FeCl}_{3} \cdot 6 \mathrm{H}_{2} \mathrm{O}\right.$, sodium hydroxide $\left.[\mathrm{NaOH}]\right)$, Nutrient broth, and Nutrient agar were purchased from HIMEDIA, India. All abovementioned chemicals were used for experimental works and are of analytical grade, which can be directly used without further purification.

\section{Screening of bioactive compounds}

The antimicrobial activity of acetone (polar), chloroform (non-polar), and aqueous (distilled water) extracts of neem (A. indica), mint (Mentha arvensis), and methi (T. foenum-graecum) against Gram-positive bacteria was evaluated using agar well-diffusion method. Aspergillus and Rhizopus were screened and isolated using potato dextrose agar (PDA) and Muller Hilton agar. Specific combination of antibiotic (i.e., streptomycin $20 \mu \mathrm{l} / 20 \mathrm{ml} /$ plate) at incubation temperature, $37^{\circ} \mathrm{C}$ in plates, and antifungal agent (i.e., fluconazole $(20 \mu \mathrm{l} / 20 \mathrm{ml} /$ plate) at incubation temperature, $28^{\circ} \mathrm{C}$ in nutrient agar, was used to evaluate growth of Aspergillus, Rhizopus, and Bacillus, respectively [28].

\section{Minimum inhibitory concentration activity (MIC)}

The MIC is defined as the lowest concentration of the antimicrobial agent that will restrict the viable and visible growth of a microorganism after incubation for $24 \mathrm{hrs}$ [29]. MIC of acetone (polar), chloroform (non-polar), and aqueous (distilled water) extracts of neem (A. indica), mint (M. arvensis), and methi (T. foenum-graecum) was determined against fungal species Rhizopus, Aspergillus, and a bacterium sps. Bacillus, respectively.

Two sets of screening studies were performed. The first set of study involved screening of antimicrobial activity of leaves of mint (Mentha), methi (T. foenum-graecum), and neem (A. indica) against Bacillus, Aspergillus, and Rhizopus sp., respectively. Inhibition of microbial growth and propagation was investigated using agar well diffusion method. Antibiotic agent, Streptomycin sulfate [30], and anti-mycotic agent, fluconazole [31], were used as a positive control. The polar, nonpolar, and aqueous extracts of plants leaves of abovementioned plant species were screened for their antibacterial activity against Bacillus sp. and antifungal activity against Aspergillus sp. and Rhizopus sp. and their mix culture, respectively.

\section{Assessment of antimicrobial potency of essential metal ions}

Antimicrobial potency of the abovementioned plant extracts against food-associated microbe was screened in the presence of essential metal ion, i.e., iron ion. The second set of study involved evaluation of combinatorial effect of plant extracts of mint (M. piperita), methi ( $T$. foenum-graecum), and neem (A. indica) complexed with ferric ions $\left(\mathrm{Fe}^{3+}\right)$ at a concentration range of 1,10 , and $100 \mathrm{mg} / \mathrm{ml}$, respectively.

Nutrient agar and PDA were prepared for methanolic, ethanolic, and aqueous extract of $A$. indica, M. arvensis, and T. foenum-graecum, respectively. $100 \mu \mathrm{l}$ of inoculum of each selected bacterium and fungus was uniformly spreaded on nutrient agar and PDA plates, respectively, with the help of glass spreader. After 15 minutes, well of $5 \mathrm{~mm}$ diameter was bored in each agar plates. Three concentration sets of equal concentration of prepared plant extracts and metal ion (ferric ion, $\mathrm{Fe}^{+}$) mixture, i.e., $1 \mathrm{mg} / \mathrm{ml}, 10 \mathrm{mg} / \mathrm{ml}$, and $100 \mathrm{mg} / \mathrm{ml}$ of plant extract and $1 \mathrm{mg} / \mathrm{ml}, 10 \mathrm{mg} / \mathrm{ml}$, and $100 \mathrm{mg} / \mathrm{ml}$, respectively, of metal ion concentration were subjected for antimicrobial evaluation. Finally, the agar plates were incubated for $24 \mathrm{hrs}$ at $37^{\circ} \mathrm{C}$ for bacterial culture and $30^{\circ} \mathrm{C}$ for fungus culture, respectively.

\section{RESULTS AND DISCUSSION}

The mounting concern for food safety and security has led to the development of antimicrobials derived from natural source to check disease causing microbial foodborne agents. A. indica [25], mentha [29], and T. foenum-graecum [30] are used in Ayurveda, Chinese medicine, and Western herbalism since ancient times as antibacterial and antifungal agent. The methanolic, ethanolic, and aqueous extracts of the above plant extracts in combination with essential metal ion 
(Ferric, $\mathrm{Fe}^{3+}$ ) showed almost two-fold inhibitory activity compared to antimicrobial efficacy of plant extracts used alone, against all three foodborne microbes [16,31].

In this study, the comparative evaluation of antimicrobial activity for the mint, methi, and neem plant extracts was performed. MIC is the lowest concentration of plant extract that inhibits the growth of visible microorganism after incubation for $24 \mathrm{hrs}$. MIC results obtained through agar well diffusion test for polar, non-polar, and aqueous extracts, respectively. MIC results for $A$. indica (neem) polar (Graph 1a), non-polar (Graph 1b), and aqueous extract (Graph 1c), T. foenum-graecum (methi) polar (Graph 2a), non-polar (Graph 2b), and aqueous extracts (Graph 2c), and mint polar (Graph 3a), non-polar (Graph 3b), and aqueous extract (Graph 3c), respectively, were evaluated in two sets of treatmentperformed simultaneously. The first set of result was obtained from direct treatment of crude plant extract on the above mentioned microbial culture at a concentration range of $1 \mathrm{mg} / \mathrm{ml}, 10 \mathrm{mg} / \mathrm{ml}$ and $100 \mathrm{mg} / \mathrm{ml}$ respectively. Second set of results was obtained from treatment of above plant extracts mixed with iron $1 \mathrm{mg} / \mathrm{ml}, 10 \mathrm{mg} / \mathrm{ml}$, and $100 \mathrm{mg} / \mathrm{ml}$, respectively, metal ions in equal concentration, i.e., $1 \mathrm{mg} / \mathrm{ml}, 10 \mathrm{mg} / \mathrm{ml}$, and $100 \mathrm{mg} / \mathrm{ml}$, respectively. It was clearly observed that the abovementioned plant extracts in combination with iron metal ions (Fe++ ions) showed the two- to three-fold high antimicrobial(antibacterial and antifungal) efficacy against Rhizopus, Aspergillus, and Bacillus species, respectively, compared to plant extracts treated alone at all concentration range used in the experiment. Furthermore, it was observed that the above aqueous plant extract-iron metal ion combination (neem, methi, and methi) showed highest (three- to four-fold) efficacy for at concentration range of $100 \mathrm{mg} / \mathrm{ml}$

Neem, methi, and mint have been considered to be potent medicinal plants [25] having significant antimicrobial property [29], and hence, it is widely used in most of the ayurvedic medicines [30]. Considering the medicinal and antimicrobial properties of the abovementioned plants, it was hypothesized that it could serve as potent inhibitor of microbial culture which spoils the packaged food products. It was further conceptualized that if the above plant extracts are coupled with iron metal ions [30,32], which is considered to be a potent antioxidant [30], it could further enhance the antimicrobial property and can be effectively used as biopackaging element, which could effectively increase the shelf life of the commercial food products. Looking into the experimental results obtained, it could be hypothesized that the interaction of plant extracts and iron oxide metal ion combination with the bacterial cell membrane may have enhanced production of reactive oxygen species (ROS) [30,33,34] in high concentration, which lead to microbial death progressively or there could be certain chemical association of $\mathrm{Fe}++$ ions with above extracts, which results in higher antimicrobial potency compared to plant extracts alone. To prove the above, hypothesis needs further investigation and experimental trails. The antimicrobial efficacy of the polar, non-polar, and aqueous extracts of mint, methi, and neem in combination and in the absence of metal ions was significantly low (two-fold reduction) and could not be continued for further assessment.

The above results (Graph 1a-c) show the comparative antibacterial efficacy of $A$. indica (neem) polar, non-polar, and aqueous extracts, respectively. The first set shows the antimicrobial potency of neem extract (leaf) in the absence of iron metal ions at an increasing concentration range of $1 \mathrm{mg} / \mathrm{ml}, 10 \mathrm{mg} / \mathrm{ml}$, and $100 \mathrm{mg} / \mathrm{ml}$, respectively. The second set of the result in the same graph shows the combinatorial efficacy of neem leaf extract and $\mathrm{Fe}^{3+}$ metal ions at an increasing concentration range of $1 \mathrm{mg} / \mathrm{ml}, 10 \mathrm{mg} / \mathrm{ml}$, and $100 \mathrm{mg} / \mathrm{ml}$, respectively, in equal concentrations. It is clearly observed from the above results that all combination of neem extract and iron metal ion shows two-fold efficacy than neem leaf extracts used alone. However, neem leaf extract (aqueous) with iron metal ion combination shows almost three-fold increase in antimicrobial activity compared to neem extract alone at all three concentrations. In addition to that, the neem extract and iron ion combination show maximum efficacy at $100 \mathrm{mg} / \mathrm{ml}$ compared to neem extract at same concentration $[35,36]$.

The above results (Graph 2a-c) show the comparative anti-bacterial efficacy of T. foenum-graecum (methi) polar, non-polar, and aqueous extracts, respectively. The first set shows the antimicrobial potency of methi extract (leaf) at an increasing concentration range of $1 \mathrm{mg} / \mathrm{ml}$, $10 \mathrm{mg} / \mathrm{ml}$, and $100 \mathrm{mg} / \mathrm{ml}$, respectively. The second set of the result in the same graph shows combinatorial efficacy of methi leaf extract and $\mathrm{Fe}^{3+}$ metal ions in equal concentrations ranging from $1 \mathrm{mg} / \mathrm{ml}$, $10 \mathrm{mg} / \mathrm{ml}$, and $100 \mathrm{mg} / \mathrm{ml}$, respectively. It is clearly observed from the above results that all combination of methi extract with iron metal ion shows two-fold higher efficacy than methi leaf extracts used alone. However, methi leaf extract (aqueous) with iron metal ion combination shows almost three-fold increase in antimicrobial activity (antibacterial and antifungal) compared to methi extract treated alone at all three concentrations. In addition to that, the methi extract and iron ion combination show maximum efficacy at $100 \mathrm{mg} / \mathrm{ml}$ compared to methi extract at the same concentration [37].

The above results (Graph 3a-c) show the comparative antibacterial efficacy of M. arvensis (mint) polar, non-polar, and aqueous extracts, respectively. The first set shows the antimicrobial potency of mint extract (leaf) at an increasing concentration range of $1 \mathrm{mg} / \mathrm{ml}$, $10 \mathrm{mg} / \mathrm{ml}$, and $100 \mathrm{mg} / \mathrm{ml}$, respectively. The second set of the result in the same graph shows combinatorial efficacy of mint leaf extract and $\mathrm{Fe}^{3+}$ metal ions in equal concentrations ranging from $1 \mathrm{mg} / \mathrm{ml}, 10 \mathrm{mg} / \mathrm{ml}$, and $100 \mathrm{mg} / \mathrm{ml}$, respectively. It is clearly observed from the above results that

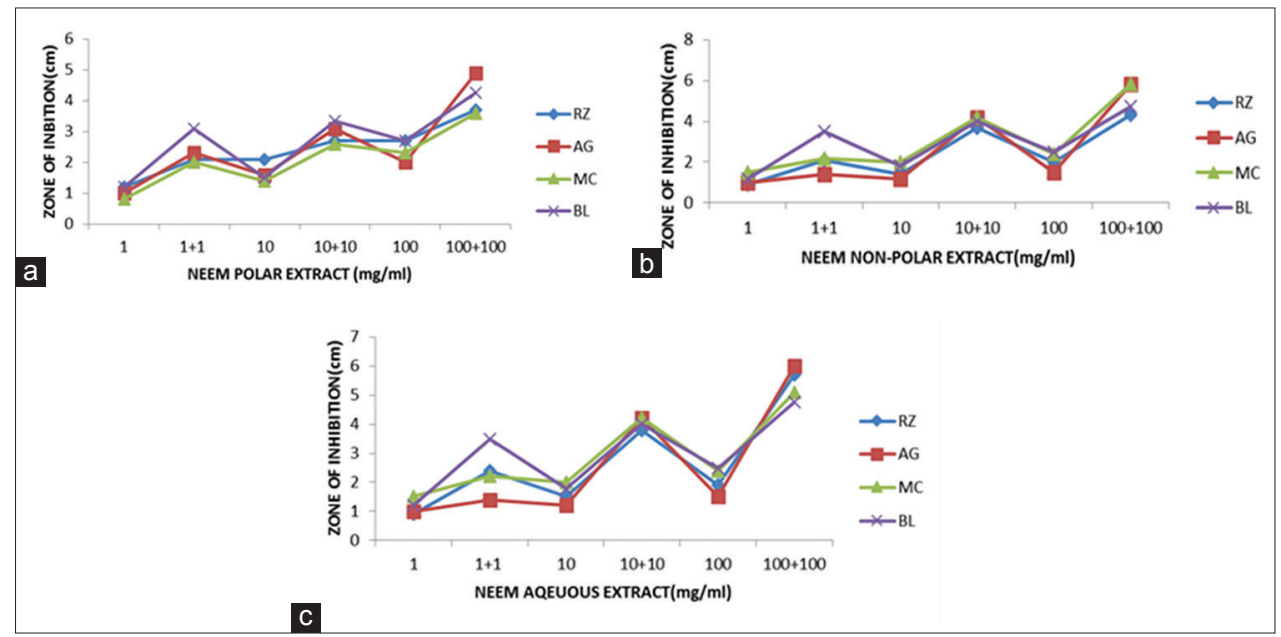

Graph 1: (a-c) Anti-microbial activity of neem (A. indica) against Rhizopus(RZ); Aspergillus (AG); Bacillus (BL); Mixed culture (MC) 


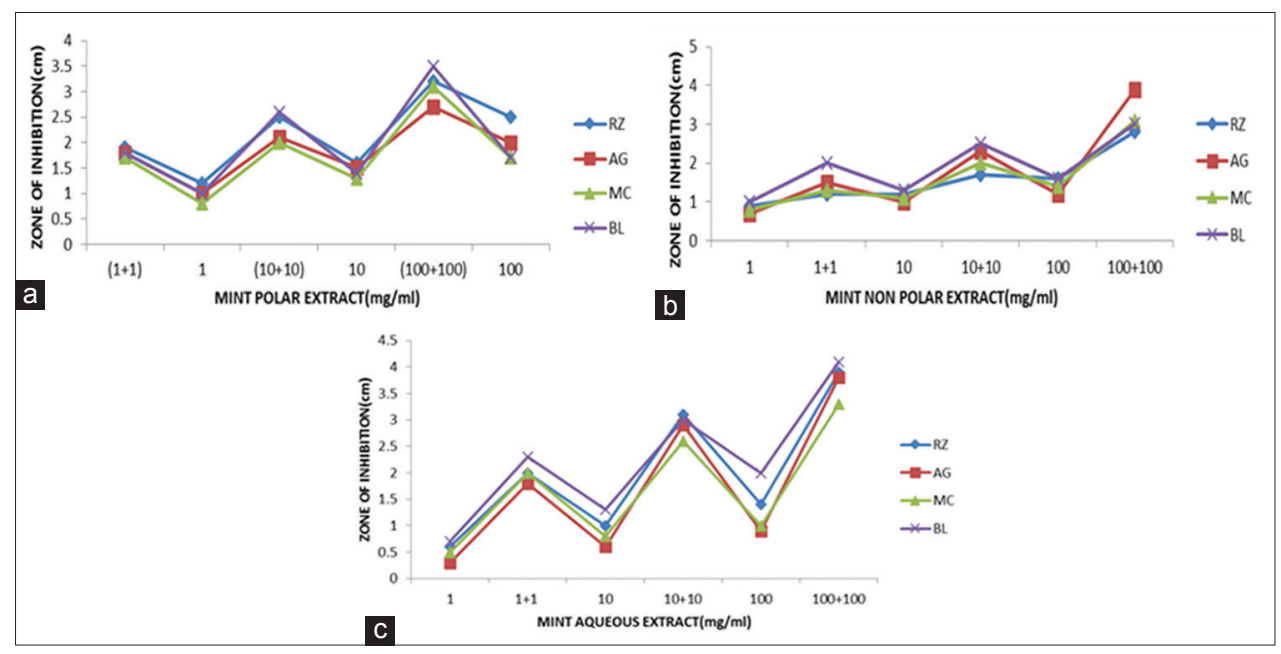

Graph 2: (a-c) Anti-microbial activity of mint (Mentha), against Rhizopus (RZ); Aspergillus (AG); Bacillus (BL); Mixed culture (MC)

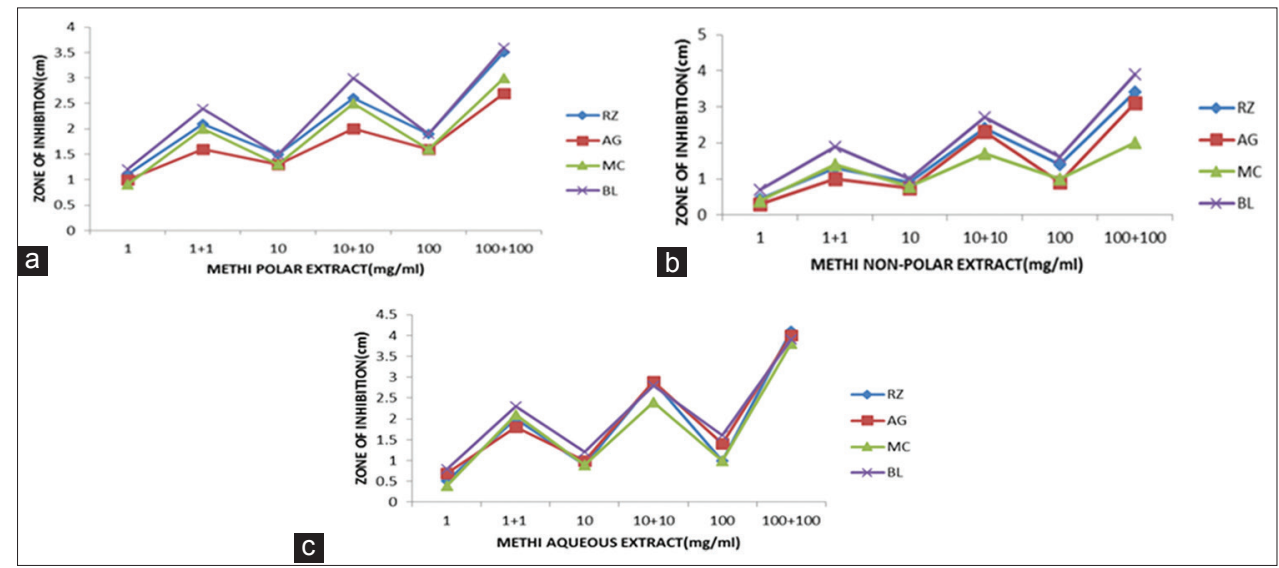

Graph 3: ( a-c) Anti-microbial activity of methi (T. foenumgraecum) against Rhizopus (RZ); Aspergillus (AG); Bacillus (BL); Mixed culture (MC)

all combination of mint extract with iron metal ion shows two-fold higher efficacy than mint leaf extracts used alone. However, mint leaf extract (aqueous) with iron metal ion combination shows almost three-fold increase in antimicrobial activity (antibacterial and antifungal) compared to mint extract treated alone at all three concentrations. In addition to that, the mint extract and iron ion combination show maximum efficacy (four fold) at $100 \mathrm{mg} / \mathrm{ml}$ compared to methi extract at the same concentration.

\section{CONCLUSION}

The above experimental study aims to justify the enhanced (2-3 fold) antimicrobial efficacy of the selected plants (neem, methi, and mint) when conjugated with iron metal ions. It was observed that aqueous extracts of all the above plant extracts when conjugated with essential iron metal ions in the concentration range of $100 \mathrm{mg} / \mathrm{ml}$ show a significant two- to three-fold increase in antimicrobial efficacy.

Based on the above investigation, it can be concluded and hypothesized that plant metabolites after conjugation with essential iron metal ions forms certain chemical combination, which shows an enhanced microbicidal property compared to plant metabolites used alone. This investigation opens a Pandora of avenues and scope of future studies to understand the chemical conjugates and recombinants in developing food packaging product and/or biopreservatives for packaged organic food products.

\section{REFERENCES}

1. Maragathavalli S, Brindha S, Kaviyarasi NS, Annadurai B, Gangwar SK. Antimicrobial activity in leaf extract of neem (Azadirachta indica Linn.). Int J Sci Nat 2012;3(1):110-3.
2. Kumbalwar $\mathrm{MM}$, Ingle $\mathrm{AB}$, Shende $\mathrm{MH}$. Antimicrobial activity of Mentha arvensis L (Pudina) against on Gram-negative bacteria. Microbiology 2014;4(4):154

3. Sun HQ, Lu XM, Gao PJ. The exploration of the antibacterial mechanism of FE(3+) against bacteria. Braz J Microbiol 2011;42:410-4

4. Legan JD. Mould spoilage of bread: The problem and some solutions. Int Biodeterior Biodegradation 1993;32(1-3):33-53.

5. Coda R, Rizzello CG, Nigro F, De Angelis M, Arnault P, Gobbetti M. Long-term fungal inhibitory activity of water-soluble extracts of Phaseolus vulgaris cv. Pinto and sourdough lactic acid bacteria during bread storage. Appl Environ Microbiol 2008;74(23):7391-8.

6. Denning DW, O'Driscoll BR, Hogaboam CM, Bowyer P, Niven RM. The link between fungi and severe asthma: A summary of the evidence. Eur Respir J 2006;27(3):615-26.

7. Arcella D, Le Donne C, Piccinelli R, Leclercq C. Dietary estimated intake of intense sweeteners by Italian teenagers. Present levels and projections derived from the INRAN-RM-2001 food survey. Food Chem Toxicol 2004;42(4):677-85.

8. Gujar JK, Talwankar D. Efficacy of some botanicals against seeding rot of oil yielding plants. Multilogic Sci 2012;2(2):122-5.

9. Sievert D, Hoseney RC. Bread and other baked products. Ullmann's Encyclopedia of Industrial Chemistry. Weinheim, Germany: Wiley-VCH; 2007.

10. Hunt L, Robbins L. Food expenditure patterns of Canadian consumers. Food Mark Comment 2009;11:42-51

11. Ibrahim MB. Anti-microbial effects of extract leaf, stem and root bark of Anogeissus leiocarpus on Staphylococcus aureaus, Streptococcus pyogenes, Escherichia coli and Proteus vulgaris. J Pharm Dev 1997:2:20-30.

12. Vinoth B, Manivasagaperumal R, Rajaravindran M. Phytochemical analysis and antibacterial activity of Azadirachta indica A. Juss. Int J Res Plant Sci 2012;2(3):50-5. 
13. Kumar PS, Mishra D, Ghosh G, Panda CS. Biological action and medicinal properties of various constituent of Azadirachta indica (Meliaceae): An overview. Ann Biol Res 2010;1(3):24-34

14. Mann A, Banso A, Clifford LC. An antifungal property of crude plant extracts from Anogeissus leiocarpus and Terminalia avicennioides. Tanzan J Health Res 2008;10(1):34-8.

15. Marchand E, Verellen-Dumoulin C, Mairesse M, Delaunois L, Brancaleone P, Rahier JF, et al. Frequency of cystic fibrosis transmembrane conductance regulator gene mutations and 5T allele in patients with allergic bronchopulmonary aspergillosis. Chest 2001;119(3):762-7.

16. Mondall NK, Mojumdar A, Chatterje SK, Banerjee A, Datta JK, Gupta S. Antifungal activities and chemical characterization of Neem leaf extracts on the growth of some selected fungal species in vitro culture medium. J Appl Sci Environ Manage 2009;13(1):49-53.

17. Niku-Paavola ML, Laitila A, Mattila-Sandholm T, Haikara A. New types of antimicrobial compounds produced by Lactobacillus plantarum. J Appl Microbiol 1999;86(1):29-35.

18. O'Driscoll BR, Hopkinson LC, Denning DW. Mold sensitization is common amongst patients with severe asthma requiring multiple hospital admissions. BMC Pulm Med 2005;5(1):4.

19. Okkers DJ, Dicks LM, Silvester M, Joubert JJ, Odendaal HJ. Characterization of pentocin TV $35 \mathrm{~b}$, a bacteriocin-like peptide isolated from Lactobacillus pentosus with a fungistatic effect on Candida albicans. J Appl Microbiol 1999;87(5):726-34.

20. Pattison TL, Lindsay D, Von Holy A. Natural antimicrobials as potential replacements for calcium propionate in bread. S Afr J Sci 2004;100(7-8):342-8.

21. Barnes PD, Marr KA. Aspergillosis: Spectrum of disease, diagnosis, and treatment. Infect Dis Clin North Am 2006;20(3):545-61, vi.

22. Rementeria A, López-Molina N, Ludwig A, Vivanco AB, Bikandi J, Pontón $\mathrm{J}$, et al. Genes and molecules involved in Aspergillus fumigatus virulence. Rev Iberoam Micol 2005;22(1):1-23.

23. Rizzello CG, Cassone A, Coda R, Gobbetti M. Antifungal activity of sourdough fermented wheat germ used as an ingredient for bread making. Food Chem 2011;127(3):952-9.

24. Rosenkvist H, Hansen A. Contamination profiles and characterisation of
Bacillus species in wheat bread and raw materials for bread production. Int J Food Microbiol 1995;26(3):353-63

25. Saranraj P. Microbial spoilage of bakery products and its control by preservatives. Int J Pharm Biol Arch 2012;3(1):38-48.

26. Schubert MS. Allergic fungal sinusitis: Pathogenesis and management strategies. Drugs 2004;64(4):363-74.

27. Seiler D. Preservation of bakery products. In: Proceedings of the Institute of Food Science and Technology. Vol. 17; 1984. p. 31-9.

28. Cheesbrough M. District Laboratory Practice in Tropical Countries. Cambridge (UK): Cambridge University Press; 2006.

29. Sofos JN, Busta FF. Antimicrobial activity of sorbate. J Food Prot 1981;44(8):614-22.

30. Stevens DA, Moss RB, Kurup VP, Knutsen AP, Greenberger P, Judson MA, et al. Allergic bronchopulmonary aspergillosis in cystic fibrosis - State of the art: Cystic Fibrosis Foundation Consensus Conference. Clin Infect Dis 2003;37 Suppl 3:S225-64.

31. Tillie-Leblond I, Tonnel AB. Allergic bronchopulmonary aspergillosis. Allergy 2005;60(8):1004-13.

32. Voysey PA, Hammond JC. Reduced-additive breadmaking technology. In: Technology of Reduced-Additive Foods. US: Springer; 1993. p. 80-94.

33. Sharma Y, Bhardwaj M, Nagar A, Bhagat N. Isolation and characterization of MDR bacteria from in-vitro culture of Bacopa monnieri and supplementation of natural extracts to control bacterial contamination. Int J Pharm Pharm Sci 2013;8(11):102-7.

34. Sharma Y, Nagar A, Shukla S. Antibacterial activity and phytochemical screening of Adenium obesum (Desert rose) leaf. Int J Pharm Bio Sci 2015;6(3):85-92

35. Gupta Y, Sharma D, Sharma Y. Bactericidal activity of different parts of Azadirachta indica on probiotic microbes. Asian J Pharm Clin Res 2016;9:50-3

36. Bounds G. Death by mint oil: Natural pesticides. Wall St J 2009.

37. Mattazi N, Farah A, Fadil M, Chraibi M, Benbrahim KF. Essential oils analysis and antibacterial activity of the leaves of Rosmarinus officinalis, Salvia officinalis and Mentha piperita cultivated in Agadir (Morocco). Int J Pharm Pharm Sci 2015;7(9):73-9. 